\title{
Parental Policies: A Catalyst for Gender Equality in the Arab Region
}

\section{Mehrinaz El Awady}

To cite this article: El Awady, M. (2018). Parental Policies: A Catalyst for Gender Equality in the Arab Region. Al Raida, 42(2), 22-32. DOI: 10.32380/alrj.v42i2.1740

To link to this article: http://dx.doi.org/10.32380/alrj.v42i2.1740

(C) 2018 The Author(s)

Corresponding author: Mehrinaz El Awady

Author contact: elawady@un.org

Article type: Article

Article accepted: 24th October 2018

Published online: $30^{\text {th }}$ November 2018

Publisher: Institute for Women's Studies in the Arab World

Publication support provided by: Escienta

Journal ISSN: 0259-9953

Copyright: This is an Open Access article, free of all copyright, and may be freely reproduced, distributed, transmitted, modified, built upon, or otherwise used by anyone for any lawful purpose. The work is made available under the Creative Commons Attribution (CC-BY) 4.0 license 


\section{Parental Policies: A Catalyst for Gender Equality in the Arab Region}

\section{Mehrinaz El Awady}

United Nations Economics and Social Commission for Western Asia, Beirut, Lebanon

The struggle for gender equality has many facets, but one crucial aspect that is often overlooked is the role of parental policies. This refers to laws stipulating that women and men should be given time off work during and after the birth of a child. Parental policies are widely viewed as important labor rights and are enshrined under various international treaties, but the broader societal value of these policies in transforming gender dynamics and promoting equality is sometimes underappreciated.

Parental policies include three elements: maternity leave, paternity leave, and parental leave. In most cases maternity leave refers to leave granted to mothers as a welfare measure to protect the health of mother and child. This kind of leave starts before childbirth and extends to after the birth. Paternity leave is granted to fathers after the birth of a child to spend time with the mother and the newborn. Parental leave is equally available to mothers and fathers who have young children, with the aim of allowing parents to spend time with the child (Moss, 2012).

In the Arab region, labor laws governing parental policies continue to lag behind international norms. This contributes significantly to women's low levels of participation in the labor market, personal choices that are affected by this limitation, and the persistence of patriarchal power dynamics within the home. There are two aspects to this issue, both of which will be discussed in more detail below. First, when there are inadequate stipulations to ensure 
women's leave during and after the birth of a child, many women feel that they cannot have both a family and a career. The physical and pragmatic conditions associated with advanced pregnancy, childbirth, and caring for a young child may make it impossible for women to retain their employment after becoming pregnant and giving birth. Second, even when there are policies in place that provide some reprieve to mothers, the absence of paternity leave reinforces the assumption that men should not be involved in child-rearing or domestic tasks. When men are given no time off to help care for children, the burden of those responsibilities almost always defaults to women, thereby reinforcing traditional gendered divisions of labor and making it difficult for mothers to hold down jobs (Moss, 2012).

The implementation of parental policies can thus have a profound impact on the choices available to women and their children, as well as on broader social perceptions of women's roles and gender stereotypes. In this context, discussing parental policies purely from the point of view of labor protection and/or women's health is insufficient and may actually be misleading. These policies need to be considered with a full understanding of how they interact with conventional gender norms, socioeconomic development, and the overall welfare of society. This paper takes a broad view of parental policies in the Arab region, and outlines the need for vigorous protections for both mothers and fathers as an intrinsic contribution to the United Nations (UN) Sustainable Development Goals (SDGs). It argues that in the absence of comprehensive parental policies aligned with international standards, gender equality in the Arab region will remain elusive.

\section{Why Do Parental Policies Matter for the SDGs?}

The availability of rigorous parental leave policies is strongly correlated with reductions in gender wage gaps, and with women's decisions to continue paid employment after becoming pregnant. For example, longitudinal studies in Sweden (Duvander, Ferrarini, \& Thalberg, 2015) and Japan (Yamaguchi, 2016) indicate that first-time mothers benefiting from parental leave policies are much more likely to continue in their jobs compared with those not covered by such policies. In the U.S., changes in Google's corporate policy to provide greater family leave led to a nearly 50 percent reduction in new mothers resigning their positions (Wojcicki, 2014). Unfortunately, the 
improved situation at Google does not reflect the overall pattern in the U.S.: the world ranking of the U.S. in terms of female labor force participation dropped from sixth place in 1990 to 17th place in 2010, in part due to inadequate parental leave policies at the national level (Blau \& Kahn, 2013).

Similar evidence is provided by a recent research finding in Denmark that women's earnings after the birth of their first child drop significantly, with no comparable decline for men. This reduction in earnings leads to almost 20 percent less income over the course of a mother's career (Kleven \& Landais 2018).

The decision to drop out of the labor force after becoming pregnant has in turn been shown to have a profound effect on women's ability to control their own finances, as well as on a variety of social factors such as the gendered distribution of household work, internal family dynamics, power relationships, and family spending patterns including investment in children's healthcare and education (Salamone, 2010). When mothers and fathers are not given adequate time to care for their children, the weight of these responsibilities almost always defaults to mothers, making it impossible for them to compete with men in accessing jobs or obtaining equal pay.

Researchers have demonstrated conclusively that women's inability to maintain employment and control their own finances is a major factor that binds women and children to abusive relationships (Salamone, 2010). The World Health Organization lists women's lack of access to employment or a decent stable income among the primary risk factors associated with violence against women, not only at the household level, but at the levels of the community and wider society (World Health Organization, 2017). This does not mean that financially independent women are immune to discrimination or violence; but when a mother feels secure in her ability to maintain a stable income through employment, she has a greatly expanded range of choices to manage threatening personal circumstances and eventually overcome them.

The role of employment in helping women to escape abusive relationships is fully evident in the Arab region, where financial independence frequently serves either as a coping mechanism for women or as a way to put an end to violence (UN Women, 2013). Having secure employment enormously helps women who need legal assistance, medical care, or an alternate residence. Perhaps most importantly, the ability to hold down a job allows mothers to financially support 
their children and afford their children's education, a common obstacle to women's ability to leave abusive relationships.

In the broader social and civic context, women's participation in the formal job market is strongly linked to their capacity to influence political decision-making. Financial insecurity and exclusive responsibility for childcare reduces women's practical ability to participate in public life and exercise their political and civil rights. Studies have shown that financial dependency is among the key socioeconomic barriers to women's political participation in the Arab region (ESCWA, 2013). In addition to these direct financial and practical obstacles, policies that do not allow adequate maternal and paternal leave reinforce the cultural ideology that women have little place in public life, and that the proper place of mothers is to retreat from the marketplace and remain in the home (Joseph, 1996).

What all of this evidence shows is that first, parental policies have a tremendous impact on women's ability to sustain careers and participate in the labor market. The importance of this factor in maintaining women's employment rates cannot be overstated. Second, dropping out of the labor market has a huge impact on nearly all aspects of women's lives, especially on their capacity for self-determination and a life free of discrimination. Parental policies therefore have an oversized effect in the realm of gender equality.

Goal 5 of the UN's SDGs is to establish gender equality. In discussions of how to achieve this goal, women's financial independence tends to be one of the first topics mentioned, and it is regarded as a vital factor to help end all forms of discrimination (Target 1 of SDG 5). As the above discussion has demonstrated, the consequences of parental policies also go far beyond women's health and labor participation, and have extensive impacts on violence against women (Target 2 of SDG 5) and on women's full and effective participation in civic life (Target 5 of SDG 5).

\section{The Wider Economic Impacts of Parental Policies}

Fortunately, as countries come to realize the social and developmental benefits of fully including women in the formal economy, they tend to become more eager to put into place national policies that will boost women's participation in the job market. A recently published 
study by the McKinsey Global Institute shows that the world could add as much as \$12 million to the global gross domestic product (GDP) by implementing policies that advance women's equality. The realization that gender equality is not only a moral and social issue but also brings great economic advantages can be an important motivating force to encourage public and private actors worldwide to enact policies to close the gender gap, both at work and on the societal level (McKinsey Global Institute, 2015). For example, one study recently estimated that India could add up to $\$ 770$ billion to its GDP by enacting policies, including maternal and paternal leave, to help keep women in the workforce (Tandon, 2018). Countries in the Arab region could gain similar economic advantages by more fully leveraging women's talents.

When women drop out of the workforce, this has a negative economic effect not only on that individual woman and her family, but also on businesses and the country as a whole. The loss of expertise due to women leaving the workforce after becoming pregnant is substantial, and the cost of finding and training replacements can be a major business expense (Boushey, 2012). In addition, there are significant morale and productivity benefits among female employees when they do not anticipate having to leave their jobs in order to start families. The presence of robust parental leave policies tends to generate greater interest in developing professional skills among women and a greater commitment to their jobs. In a broad U.S. study, researchers found that 99 percent of employees agreed that having strong parental leave policies increased their morale. The same study found that 91 percent of employers described these policies as having either a "positive effect" or "no noticeable effect" on the company's profitability (Appelbaum \& Milkman, 2011).

Due to their economic implications, rigorous parental policies promote multiple SDGs and targets, even beyond the specific goal of gender equality. Such policies can mitigate broad macroeconomic and unemployment problems and help reduce poverty. By encouraging women to remain in the workforce, better parental policies can help protect the economic welfare of vulnerable populations (SDG 1, especially Target 3). Parental policies are also vital to ensure full and productive employment and decent work for all (SDG 8, Target 5) and to promote social, economic, and political inclusion (SDG 10, Target 2) (International Labor Organization, 2017a). 
Parental Policies in the Arab Region: One of the Many Faces of Gender Inequality

Only a few countries in the Arab world, including Algeria, Mauritania, and Morocco, currently meet the international standard of 14 weeks' mandatory maternity leave for women (International Labor Organization, 2017b). Others, including Oman, Bahrain, Yemen, and Iraq, mandate between seven and nine weeks of maternity leave. In most of the region, maternity protections are sparse, and when female employees become pregnant or need to care for infants it is widely regarded as a personal issue for women to handle on their own. Paternity leave is almost non-existent in the region, to the extent that Jordan's recent decision to implement a twoday leave for men when their wives give birth was hailed as a significant step forward (Husseini, 2018). This weakness in parental policies is tied to a strong conventional expectation that women will leave their jobs and devote themselves fully to childcare after they become pregnant. Very often, this means that even mothers who would like to continue working must make a mental cost-benefit analysis, weighing the value of their income against the extreme difficulty of having full responsibility for an infant while trying to continue in an unsupportive employment environment. This result of this cost-benefit analysis usually leads to women leaving work.

The issue of parental policies in the Arab region cannot be discussed in isolation from the overall state of gender equality. The region continues to rank extremely poorly in measures such as the World Economic Forum's Global Gender Gap Report (which captures the magnitude of gender-based disparities in four thematic dimensions: economic participation and opportunity, educational attainment, health and survival, and political empowerment) (World Economic Forum, 2017). The region also lags behind in social progress more broadly. The newly developed Social Progress Index, which incorporates social, environmental, and economic factors, has given low ratings to many countries in the region. For example, in 2017, of 133 countries included in the global ranking, Kuwait was ranked 42nd, Tunisia 51st, and Jordan 56th (Social Progress Index, 2017).

Arab women's participation in the labor market stands at 23 percent, far below the global average of 50 percent. Furthermore, this 23 percent of women who do hold jobs tend to work in limited fields of employment (generally "soft sectors" such as education and agriculture), with 
minimal prospects for elevation to managerial or executive positions (ESCWA, 2016a). While the region has made some advances in areas such as women's education and literacy, these achievements have not translated fluidly into widespread social change or the promotion of women into positions of political and financial power (Inter-Parliamentary Union, 2018).

The poor socioeconomic status of women in the Arab region, combined with the lack of robust legal accountability, is supported by conditions described by Deniz Kandiyoti as "classic patriarchy" (Kandiyoti, 1988). Under this system, men exert power over women by controlling their bodies and mobility, often bolstered by conservative interpretations of religion. This control and discrimination is normalized within the family and society to such an extent that it is sometimes not even understood as abuse, but rather as protection and care (Said-Foqahaa, 2011). Women (and non-conforming men) face severely limited life prospects, frequent stress and insecurity, and high rates of domestic violence. The effects of these experiences in turn limit women's practical and psychological capacities to seek independence, perpetuating the cycle of inequality.

The situation is often worse for women who experience intersecting forms of marginalization, such as those belonging to minority religious or ethnic groups, or those who have disabilities (Office of the United Nations High Commissioner for Human Rights, 2008). In the Arab region, another prominent intersecting factor is the large number of low-income women working in the informal sector. This refers to temporary paid labor that is "off the books" and thus largely absent from the scrutiny of any regulating agencies. Often these women work in hazardous conditions, and if they are unavailable for work due to pregnancy or other personal circumstances, they receive no compensation. Women who work in the informal sector are not provided with maternity leave; they are therefore likely to continue working into late stages of pregnancy, and sometimes return to work immediately after childbirth to avoid loss of income. This can have serious health consequences for low-income mothers and their children (International Labor Organization, 2017).

The region's public conflicts have taken a heavy toll on women and other marginalized groups, including the unrest that swept through the Arab region in late 2010. This conflict led to major transformations in the status quo. In many areas, the unrest exacerbated preexisting gender 
inequalities (International Labor Organization, 2017). Women living in conflict-affected countries experienced high rates of displacement and became more involved in informal work. As men became involved in conflicts or went missing, increasing numbers of women were obliged to take whatever jobs they could find to secure a minimum income for their families, in addition to maintaining their traditional caregiver roles. These circumstances significantly increased the number of women accepting menial jobs and jobs without formal protection schemes (ESCWA, 2016b).

The reluctance of states in the Arab region to invest in strong parental policies is linked to entrenched ideas about gender roles that reinforce traditional power inequalities. These ideologies prevent many leaders from recognizing the social and economic benefits that can result from empowering women. The implementation of successful parental policies in the Arab region is thus a multifaceted problem that will require the overcoming of widespread social conservativism about gender roles, as well as the extension of business regulations to the informal economy. However, this is exactly why the successful establishment of parental policies aligned with international standards will be socially transformative. In this sense, parental policies can be seen as a key issue around which the substance and sincerity of commitments to gender equality can be tested.

\section{Conclusion: A Forward-Looking Approach}

The cycle of discrimination, sexism, and gender inequality is hard to break in the Arab region. Serious coordinated action is required to rectify this injustice and eliminate its negative implications. Rigorous parental policies to ensure both maternal and paternal leave can be a significant part of the solution. Decent maternity leave has proven in numerous countries to increase female participation in paid work, enhance women's representation in high-profile occupations, empower women in the financial and familial spheres, and enhance women's overall participation in civic life. At the same time, paternal leave will promote fairness in financial and domestic tasks, and will help to reshape gender dynamics and power relationships within the 
household. Overall these policies will nudge society strongly in the direction of greater economic prosperity, and a fairer and more balanced sharing of personal responsibilities and agency.

If the Arab region is to adopt a forward-looking approach, national governments must understand that it is their role to enforce and in some cases subsidize parental policies. This should be part of a comprehensive welfare approach involving labor regulation, healthcare, and social protection. In addition to requiring full periods of paid parental leave for both women and men, governments can also introduce early childhood service programs and educational initiatives, to help women and men be better parents and to allow mothers to continue working without feeling guilty. Being knowledgeable about healthy childcare standards, and being assured that their children are well taken care of while they are at work, is fundamental to enabling mothers to act with confidence and continue their participation in the formal economy. The benefits of such programs are intergenerational as well, since they provide professional-standard care and supervision for children in a social learning environment.

Arab states also need to bid farewell to a default economic model that is based on men as sole breadwinners and women as domestic support. To promote better parental policies and gender equality, it may be useful to promote awareness and discussion of how retaining women in the workplace can expand the overall economy and promote economic development. Higher rates of employment, greater purchasing power, and more tax revenues for infrastructure and education will help to make society more enjoyable and comfortable for everyone. In addition to empowering women, it is vital for men to understand that they too can be better off if they set aside their patriarchal authority and work with women as equal partners.

Relying on narrow pleas for women's health and protection, as some advocates currently do, is unlikely to be successful in achieving rigorous parental policies or associated social transformations. Instead, governments and non-state actors should combine a coherent legal policy framework with substantial awareness-raising campaigns that emphasize the important role played by both parents in childcare and the need for new mothers and fathers to have several months of leave before returning to the workforce. Such campaigns can leverage a prominent discussion of parental policies as a means to support substantive gender equality and promote egalitarian domestic arrangements as a norm. 
If gender equality is to become a reality in the Arab region, national governments will have to go a long way to match their efforts with international standards of due diligence. These due diligence considerations include the key principles that the state cannot delegate its obligations to non-state actors, and that the commitment to promote gender equality must be implemented in good faith (Erturk, 2017). By accepting this responsibility and emphasizing parental policies as a central aspect of their gender equality efforts, governments in the Arab region can create admission tickets for women to fully participate in public life and the workforce. In doing so they will make great strides toward a healthier society and become true leaders in advancing the international community's SDGs.

\section{References}

Appelbaum, E., \& Milkman, R. (2014). Leaves that pay: Employer and worker experiences with paid family leave in California. Members-only Library.

Blau, F. D., \& Kahn, L. M. (2013). Female labor supply: Why is the US falling behind? (No. w18702). National Bureau of Economic Research.

Boushey, H., \& Glynn, S. J. (2012). There are significant business costs to replacing employees. Center for American Progress, 16.

Duvander, A. Z., Ferrarini, T., \& Thalberg, S. (2005). Swedish parental leave and gender equalityAchievements and reform challenges in a European perspective (No. 2005: 11). Institute for Futures Studies.

Erturk, Y. (2016). Violence without borders: Paradigm, policy, and praxis concerning violence against women. Bethesda, MD: Women's Learning Partnership.

ESCWA. (2013). Arab women's participation in public life: Challenges and opportunities.

ESCWA. (2016a). Against wind and tides: A review of the status of women and gender equality in the Arab region. Retrieved from

https://www.unescwa.org/sites/www.unescwa.org/files/publications/files/women-genderequality-arab-region.pdf

ESCWA. (2016b). Socioeconomic impact of conflict on women and girls in the Arab Region. ESCWA

Husseini, R. (2018, February 28). Women's movement hails gender sensitive amendments to labor law. Jordan Times. Retrieved from http://www.jordantimes.com/news/local/women\%E2\%80\%99smovement-hails-gender-sensitive-amendments-labour-law

Inter-Parliamentary Union. (2018). Women in national parliaments. Retrieved from http://archive.ipu.org/wmn-e/classif.htm (1st June 2018)

International Labor Organization. (2017a). World social protection report: Universal social protection to achieve the Sustainable Development Goals.

International Labor Organization. (2017b). World social protection report.

Joseph, S. (1996). Patriarchy and development in the Arab world. Gender \& Development, 4(2), 14-19.

Kandiyoti, D. (1988). Bargaining with patriarchy. Gender \& society, 2(3), 274-290. 
Kleven, H., Landais, C., \& Søgaard, J. E. (2018). Children and gender inequality: Evidence from Denmark (No. w24219). National Bureau of Economic Research. Retrieved from https://www.henrikkleven.com/uploads/3/7/3/1/37310663/kleven-landais-sogaard_nberw24219_jan2018.pdf

Woetzel, J. (2015). The power of parity: How advancing women's equality can add \$12 trillion to global growth (No. id: 7570).

Moss, P. (Ed.). (2012). International review of leave policies and related research 2012. International Network on Leave Policies and Related Research.

Office of the United Nations High Commissioner for Human Rights. (2008). Project on a mechanism to address laws that discriminate against women. https://www.un.org/ruleoflaw/files/laws_that_discriminate_against_women.pdf

Violence Against Women with Disabilities Working Group. (2012). Forgotten sisters: A report on violence against women with disabilities: An overview of its nature, scope, causes and consequences. Retrieved from https://repository.library.northeastern.edu/files/neu:332599/fulltext.pdf

Said-Foqahaa, N., \& Maziad, M. (2011). Arab women: Duality of deprivation in decision-making under patriarchal authority. Hawwa, 9(1), 234-272.

Salamone, N. (2010). Domestic Violence And Financial Dependency. Forbes, September, 2.

Social Progress Index (2017). Retrieved from https://www.socialprogressindex.com/

Tandon, S. (2018, April 26). India could boost its GDP by $\$ 770$ billion by just treating women better. Quartz India. Retrieved from https://qz.com/1261691/how-india-could-boost-its-gdp-by-770billion-according-to-mckinsey/

World Economic Forum. (2017). The global gender gap report. Retrieved from https://www.weforum.org/reports/the-global-gender-gap-report-2017

World Health Organization. (2017). Violence against women. Retrieved from http://www.who.int/newsroom/fact-sheets/detail/violence-against-women

Wojcicki, S. (2014, December 16). Paid maternity leave is good for business. The Wall Street Journal. Retrieved from https://www.wsj.com/articles/susan-wojcicki-paid-maternity-leave-is-good-forbusiness-1418773756

Yamaguchi, S. (2017). Effects of Parental Leave Policies on Female Career and Fertility Choices. Institute of Economic Research Hitotsubashi University Institutions.

UN Women. (2013). Arab states region: State of the art. 